\title{
НОВЫЙ ПОДХОД К ПОЛУЧЕНИЮ АНТИ-ВИЧ АКТИВНЫХ ПРОИЗВОДНЫХ 5-АЛКИЛ-2-АЛКОКСИ-6-БЕНЗИЛПИРИМИДИН-4(3Н)-ОНА
}

\section{И.А. Кириллов' ${ }^{1}$ И.А. Новаков', М.Б. Навроцкий', D. Schols², П.П.Дешевов'}

${ }^{1}$ ФГБОУ ВО Волгоградский государственный технический университет, 400005, Российская Федерация, Волгоград, пр. им. Ленина, 28.

${ }^{2}$ Рега институт медицинских исследований,

B1030 3000, Бельгия, Лёвен, ул. Миндербродерстрат, 10.

DOI: 10.19163/MedChemRussia2021-2021-246

E-mail: kirillow.vania@yandex.ru

В продолжение работ [1] по направленному конструированию блокаторов ретровирусной репликации ряда производных DABO была впервые показана возможность получения этих соединений с использованием реакции алкоголиза производных $N^{2}$-нитроизоцитозина в условиях катализа третичным амином, не описанная ранее в литературе. Соответствующие превращения иллюстрируются следующей схемой реакции:<smiles>[Y4]c1c(C([R])([R])[15F])[nH]c(=[N+]([O-])[O-])[nH]c1=O</smiles><smiles>[R20]O[C@H]1CC[C@H](C)CC1</smiles><smiles>[Y4]c1c(C([R])([R])[15F])nc(O[AlH2])[nH]c1=O</smiles>

где Alk = i-Pen, $n$-Bu, $i$-Bu, $c$-Pen; $\mathrm{Ar}=2,6-\mathrm{F}_{2}-\mathrm{C}_{6} \mathrm{H}_{3}, 2,6-\mathrm{Cl}_{2}-\mathrm{C}_{6} \mathrm{H}_{3}, 2-\mathrm{F}-6-\mathrm{Cl}-\mathrm{C}_{6} \mathrm{H}_{3}, 3,5-\mathrm{Me}_{2}-\mathrm{C}_{6} \mathrm{H}_{3}$;

$$
\mathrm{R}=\mathrm{Me}, \mathrm{MeO} ; \mathrm{R}^{\prime}=\mathrm{H} ; \mathrm{R}+\mathrm{R}^{\prime}=\left(\mathrm{CH}_{2}\right)_{2}
$$

Было установлено, что в случае первичныхалифатических спиртов, а также циклоалканолов эта реакция становится основной и приводит к образованию соответствующих производных 2-алкоксипиримидин-4(3H)-она. Использование разветвленных вторичных спиртов приводит к образованию производного урацила.

Полученные впервые соединения были подвергнуты исследованиям в отношении ВИЧ-1/2 в условиях острого эксперимента invitro. Данные соединения показывают сопоставимую и более высокую активность в отношении ВИЧ-1, чем препараты сравнения, однако уступают им по анти-ВИЧ-2 активности. Структура и чистота полученных соединений доказаны с использованием современных физико-химических методов анализа.

\section{Литература}

[1]. И. А. Новаков, Л. Л. Брунилина, А.А. Вернигора, И. А. Кириллов, А. С. Мкртчян, М. Б. Навроцкий, Д. С. Шейкин, А. С. Яблоков, Е. А. Ручко, В. В. Качала. Аминолиз 6-[1-(2,6-дифторфенил)циклопропил]-5-метил-2-(нитроамино)пиримидин-4(3Н)-она // Журнал органической химии. - 2017. - Т. 53, № 12. - С. 1808-1815. 